\title{
A method to reduce ELISA serial dilution assay workload applied to SARS-CoV-2 and seasonal HCoVs
}

David Pattinson $^{\mathrm{a}, \dagger}$, Peter Jester ${ }^{\mathrm{a}, \dagger}$, Lizheng Guan ${ }^{\mathrm{a}, \dagger}$, Seiya Yamayoshi ${ }^{\mathrm{b}, \mathrm{c}, \dagger}$, Shiho Chiba ${ }^{\mathrm{a}}$, Robert

Presler Jr. ${ }^{a}$, Hongyu Rao ${ }^{a}$, Kiyoko Iwatsuki-Horimoto ${ }^{b}$, Nobuhiro Ikeda ${ }^{d}$, Masao Hagihara ${ }^{e}$, Tomoyuki Uchida ${ }^{e}$, Keiko Mitamura ${ }^{\dagger}$, Peter Halfmann ${ }^{a}$, Gabriele Neumann ${ }^{a}$, Yoshihiro Kawaoka ${ }^{a, b, g, *}$

a. Department of Pathobiological Sciences, School of Veterinary Medicine, University of Wisconsin-Madison, USA

b. Division of Virology, Department of Microbiology and Immunology, Institute of Medical Science, University of Tokyo, Japan

c. The Research Center for Global Viral Diseases, Research Institute, National Center for Global Health and Medicine, Japan

d. Department of General Internal Medicine, Eiju General Hospital, Japan

e. Department of Hematology, Eiju General Hospital, Japan

f. Division of Infection Control, Eiju General Hospital, Japan

g. Department of Special Pathogens, International Research Center for Infectious Diseases, Institute of Medical Science, University of Tokyo, Japan

†These authors contributed equally to this work.

*To whom correspondence should be addressed. Email: yoshihiro.kawaoka@wisc.edu. Postal address: Influenza Research Institute, 575 Science Dr, Madison, WI, 53711, USA. Telephone: +1 6082654925. 


\section{$\underline{\text { Conflict of interest }}$}

Declarations of interest: none.

\section{Funding}

This work was supported by the US Centers for Disease Control and Prevention [grant number: 75D30120C09259]; and the Japan Agency for Medical Research and Development [grant numbers: 20fk0108301, 20fk0108527, 20fk0108272].

\section{Abstract}

\section{Objectives}

Assays using ELISA measurements on serially diluted serum samples have been heavily used to measure serum reactivity to SARS-CoV-2 antigens and are widely used in virology and elsewhere in biology. We test a method to reduce the workload of these assays, and measure reactivity of SARS-CoV-2 and HCoV antigens to human serum samples collected before and during the COVID-19 pandemic.

\section{Methods}

We apply Bayesian hierarchical modelling to ELISA measurements of human serum samples against SARS-CoV-2 and HCoV antigens.

\section{$\underline{\text { Results }}$}

Inflection titers for SARS-CoV-2 full-length spike protein (S1S2), spike protein receptor-binding domain (RBD), and nucleoprotein $(N)$ inferred from three spread-out dilutions correlated with those inferred from eight consecutive dilutions with an $\mathrm{R}^{2}$ value of 0.97 or higher. We confirm existing findings showing a small proportion of pre-pandemic human serum samples contain cross-reactive antibodies to SARS-CoV-2 S1S2 and N, and that SARS-CoV-2 infection increases serum reactivity to the beta-HCoVs OC43 and HKU1 S1S2. 
medRxiv preprint doi: https://doi.org/10.1101/2021.09.13.21263523; this version posted September 21, 2021. The copyright holder for this preprint (which was not certified by peer review) is the author/funder, who has granted medRxiv a license to display the preprint in perpetuity.

It is made available under a CC-BY-NC-ND 4.0 International license .

\section{$\underline{\text { Conclusions }}$}

In serial dilution assays, large savings in resources and/or increases in throughput can be achieved by reducing the number of dilutions measured and using Bayesian hierarchical modelling to infer inflection or endpoint titers. We have released software for conducting these types of analysis.

Keywords

SARS-CoV-2, HCoV-OC43, HCoV-HKU1, HCoV-229E, HCoV-NL63, ELISA, Bayesian analysis, Hierarchical modelling, Endpoint assay, Inflection titer.

\section{Introduction}

Severe acute respiratory syndrome coronavirus 2 (SARS-CoV-2) emerged in December 2019 [1] and is the causative agent of coronavirus disease 2019 (COVID-19). On March 11, 2020, the outbreak was declared a pandemic by the World Health Organization (WHO) [2] and at the time of writing there have been over 206 million confirmed SARS-CoV-2 infections and 4.3 million deaths attributed to the virus globally [3]. The World Bank estimates that between 119 and 124 million people were pushed into extreme poverty by impacts of the COVID-19 pandemic in 2020 alone [4].

Coronaviruses (CoVs) more generally are separated into four phylogenetic clades: alpha-CoV, beta-CoV, gamma-CoV and delta-CoV. Four CoVs circulate continuously in humans (HCoVs), are distributed globally, and generally cause common cold or influenza-like illness [5]. These are the alpha-CoVs HCoV-229E (229E) and HCoV-NL63 (NL63), and the beta-CoVs HCoV-HKU1 (HKU1) and HCoV-OC43 (OC43). Two other beta-CoVs have also infected humans: severe acute respiratory syndrome coronavirus (SARS-CoV) and Middle East Respiratory Syndrome Coronavirus (MERS-CoV) [6,7]. The SARS-CoV outbreak in 2003 was largely contained and MERS-CoV is not well adapted for ongoing human to human transmission. 
medRxiv preprint doi: https://doi.org/10.1101/2021.09.13.21263523; this version posted September 21, 2021. The copyright holder for this preprint (which was not certified by peer review) is the author/funder, who has granted medRxiv a license to display the preprint in perpetuity.

It is made available under a CC-BY-NC-ND 4.0 International license .

At the start of the COVID-19 pandemic we lacked detailed knowledge of serological reactivity to HCoVs in the human population. It was also unknown how much cross-reactivity there was between antibodies elicited to prior HCoV infections against SARS-CoV-2. Furthermore, if crossreactivity did exist, it was not known how protective it may be against SARS-CoV-2 infection. Several studies have now measured reactivity of human serum collected before and during the COVID-19 pandemic, and through the course of SARS-CoV-2 infections against panels of HCoV antigens [8-17]. Most studies that measure human sera collected before the COVID-19 pandemic demonstrate that a small proportion of pre-pandemic sera possess cross-reactive antibodies against the SARS-CoV-2 S1S2 and N antigens $[8,9,15,17]$. Moreover, studies that measure sera collected longitudinally from COVID-19 patients show that SARS-CoV-2 infection increases serum antibody titers to certain beta-HCoV antigens, particularly OC43 [10-12,14]. This observation tends to be weaker, absent, or even reversed when comparing cohorts of unmatched samples collected before and during the pandemic $[9,15,18]$. The diverse nature of cohorts and variable circulation of HCoVs when cohorts were sampled may contribute to the sometimes conflicting reports [19].

Serology studies can be conducted using a single serum dilution in ELISA assays. This enables high sample throughput but can limit resolution if the dilution used results in measurements near to the minimum or maximum Optical Density (OD) readout of the assay. Thus, it is common to measure the OD across a series of typically 8-12 dilutions and report the dilution, known as the 'endpoint', at which the OD drops below a predefined baseline value. However, conducting ELISAs at this many serial dilutions per sample is labor- and resource-intensive. Here, we investigated if equally accurate data can be obtained from substantially fewer than 8-12 serial dilutions, by using a Bayesian hierarchical model to fit sigmoid curves to the data.

Sigmoid curves are used to fit OD values as a response to log serum concentration (Fig. S1) [20]. Once the model is fitted, quantities of interest, such as the inflection point, or any arbitrary 
medRxiv preprint doi: https://doi.org/10.1101/2021.09.13.21263523; this version posted September 21, 2021. The copyright holder for this preprint (which was not certified by peer review) is the author/funder, who has granted medRxiv a license to display the preprint in perpetuity.

It is made available under a CC-BY-NC-ND 4.0 International license .

endpoint, can be derived from the parameters describing the curve. This approach offers several benefits. Firstly, sigmoid curves can be inferred from fewer dilutions than are typically conducted. Secondly, fitting a model to multiple measurements reduces the influence of error associated with individual measurements, avoiding reliance on individual measurements used to define "the" endpoint. Thirdly, parameters are estimated on a continuous scale in between discrete dilution folds, increasing resolution. Fourthly, samples from ELISA datasets often share properties such as the maximal response ('saturation' point of the ELISA), minimal response (the OD value of the background or negative control) and gradient of the sigmoid curve. When properties are shared among samples, hierarchical modelling allows measurements from all samples to contribute to the inference of the shared properties. Data from a single sample does not have to be able to accurately infer these properties in isolation; only parameters of interest, such as the horizontal shift of the sigmoid, need to be inferred on a per-sample basis.

As stated earlier, most ELISA studies report an 'endpoint' titer, defined as the first dilution in the series at which an OD value below a cutoff is measured. Cutoffs are determined by either choosing a low absolute OD value, computing a low proportion of the maximal response, or computing a multiple of the mean background or negative control. Frey et al. [21] advocate a less arbitrary method based on computing the prediction limit of the negative control. The primary variation of interest when comparing dilution series between samples is the extent to which the sigmoid curves are shifted to the left or right on the x-axis (Fig. S1). The location of a sigmoid curve relative to the $\mathrm{x}$-axis is defined by its inflection point (parameter a, Fig. S1). In the context of a titration assay we refer to this inflection point as the 'inflection titer'. Rather than comparing arbitrarily defined endpoint titers, we focus our analysis primarily on comparing inflection titers. We note that once the parameters of a sigmoid curve are inferred, it is elementary to compute the endpoint at any arbitrary cutoff value. 
medRxiv preprint doi: https://doi.org/10.1101/2021.09.13.21263523; this version posted September 21, 2021. The copyright holder for this preprint (which was not certified by peer review) is the author/funder, who has granted medRxiv a license to display the preprint in perpetuity.

It is made available under a CC-BY-NC-ND 4.0 International license .

Here, we tested serum samples from several cohorts (collected before the SARS-CoV-2 pandemic, collected from individuals who tested PCR-positive for SARS-CoV-2, and collected from individuals early and late during SARS-CoV-2 infection) in ELISAs against SARS-CoV-2 and seasonal HCoVs. This comprehensive dataset was then used to test if a reduced number of serial dilutions can be used to accurately infer inflection titers in a Bayesian hierarchical modelling framework. We demonstrate that only three serum dilutions are sufficient to recapitulate inflection titers obtained with eight serum dilutions, resulting in substantial time and resource savings.

\section{Materials Methods}

\section{Human serum samples}

248 samples were purchased commercially before the emergence of SARS-CoV-2 (64 from Lampire Biological Laboratories, 184 from BiolVT). 188 samples were collected from individuals at the University of Wisconsin-Madison Hospital (UWH) after testing PCR-positive for SARS-CoV2; no further tests (such as serology test or virus isolation) were conducted to confirm the PCR results. 12 SARS-CoV-2 positive samples were purchased from Lampire Biological Laboratories (commercial positive). 44 paired samples were collected at the Eiju General Hospital (EGH), Tokyo, Japan early and late during SARS-CoV-2 infection. Early and late samples were collected on average 2.0 (standard deviation 4.8) and 29.5 (standard deviation 9.6) days after symptom onset, respectively. Four samples were from asymptomatic patients, for which the day of RTqPCR positive test was used as the day of onset. 162 samples were collected by the Marshfield Clinic Research Institute (MCRI), Marshfield, Wisconsin after the emergence of SARS-CoV-2. Groups of samples used in this study are summarized in Table S1. 
medRxiv preprint doi: https://doi.org/10.1101/2021.09.13.21263523; this version posted September 21, 2021. The copyright holder for this preprint (which was not certified by peer review) is the author/funder, who has granted medRxiv a license to display the preprint in perpetuity.

It is made available under a CC-BY-NC-ND 4.0 International license .

\section{Ethics and biosafety statements}

University of Wisconsin: The study was approved by the Human Subjects Institutional Review Boards at the University of Wisconsin and signed informed consent was obtained from each participant at each time point before collection. MCRI: Human samples were collected after informed consent by protocols approved by the MCRI's Institutional Review Board. IMSUT: Human samples were collected by following protocols approved by the Research Ethics Review Committee of the Institute of Medical Science, the University of Tokyo (approval number 201971-0201). Signed informed consent was obtained from all participants.

\section{$\underline{\text { Antigens }}$}

SARS-CoV-2 full-length spike protein (S1S2) and its receptor-binding domain (RBD) were expressed in Expi293F cells and purified using TALON metal affinity resin (Thermo Fisher Scientific) following the Krammer group protocol [22]. The S1S2 construct included the 'hexaproline' stabilizing amino acid $\quad$ (AA) substitutions (F817P/A892P/A899P/A942P/K986P/V987P) [23], the cleavage site RRAR (682-685) was replaced with GSAS, and AA15-1208 was followed by T4 foldon trimerization motif, 3C protease cleavage site, and hexa-histidine tag (AA1-14 is a signal peptide). AA319-541 were used as the RBD. Other antigens were purchased from Sino Biological (OC43 S1S2, catalog number 40607V08B; HKU1 S1S2, 40606-V08B; NL63 N, 40641-V07E; 229E N 40640-V07E; SARS-CoV-2 N 40588-V08B), BPS Bioscience (NL63 S1S2, 100788), Creative Diagnostics (OC43 N, DAGB101), The Native Antigen Company (229E S1S2, REC31880-100) and Aviva Systems Biology (HKU1 N, OPCA203310). 
medRxiv preprint doi: https://doi.org/10.1101/2021.09.13.21263523; this version posted September 21, 2021. The copyright holder for this preprint (which was not certified by peer review) is the author/funder, who has granted medRxiv a license to display the preprint in perpetuity.

It is made available under a CC-BY-NC-ND 4.0 International license .

\section{ELISA}

$\mid \mathrm{RI}$

ELISA on pre-pandemic, UWH PCR positive, commercial positive and MCRI samples was conducted at the Influenza Research Institute (IRI), University of Wisconsin-Madison, as follows. 96-well ELISA plates (Thermo Scientific \#:14245153) were coated with antigen at $100 \mathrm{ng} / \mathrm{well}$ and incubated overnight at $4{ }^{\circ} \mathrm{C}$. Plates were blocked with PBS containing $0.1 \%$ Tween-20 (PBS-T) and $3 \%$ milk for $1 \mathrm{~h}$ at room temperature and washed. All washes were conducted three times with PBS-T. Sera were diluted 1:40 in PBS-T and 1\% milk. For titration series, sera were further diluted in PBS-T and 1\% milk in 1:4 steps to a lowest concentration of 1:655,360. $100 \mu$ of each sera was added to the ELISA plates and incubated for 2-4 $\mathrm{h}$ at room temperature. Anti-human IgG-Peroxidase antibody produced in goat (Sera Care-KPL \#.5220-0277), diluted 1:3000 in PBST and $1 \%$ milk, was used as the secondary antibody. Plates were washed and incubated for $1 \mathrm{~h}$ at room temperature with $50 \mu \mathrm{l} /$ well of diluted secondary antibody. Plates were washed, and then incubated with $100 \mu \mathrm{I}$ OPD solution (SIGMAFAST TM OPD, Sigma-Aldrich \#P9187) for 10 min at room temperature. The reaction was stopped by adding $50 \mu \mathrm{l} 3 \mathrm{M} \mathrm{HCl}$ and the OD at $490 \mathrm{~nm}$ was measured.

\section{IMSUT}

ELISA on EGH samples was conducted at the IMSUT as described previously [24]. 96-well Maxisorp microplates (Nunc) were incubated with $100 \mathrm{ng} /$ well of recombinant protein or PBS at $4^{\circ} \mathrm{C}$ overnight and then incubated with $5 \%$ skim milk in PBS containing $0.05 \%$ Tween -20 for $1 \mathrm{~h}$ at room temperature. Serum samples were diluted 1:40 in PBS-T containing 5\% skim milk. Microplates were reacted for $1 \mathrm{~h}$ at room temperature with the diluted serum samples, followed by peroxidase-conjugated goat anti-human IgG, Fcy Fragment specific antibody (Jackson ImmunoResearch \#109-035-098). 1-Step Ultra TMB-Blotting Solution (Thermo fisher scientific) 
medRxiv preprint doi: https://doi.org/10.1101/2021.09.13.21263523; this version posted September 21, 2021. The copyright holder for this preprint (which was not certified by peer review) is the author/funder, who has granted medRxiv a license to display the preprint in perpetuity.

It is made available under a CC-BY-NC-ND 4.0 International license .

was then added to each well and incubated for $3 \mathrm{~min}$ at room temperature. The reaction was stopped by adding $2 \mathrm{M} \mathrm{H}_{2} \mathrm{SO}_{4}$ and the $\mathrm{OD}$ at $450 \mathrm{~nm}$ was measured.

\section{$\underline{\text { Statistical analyses }}$}

At least two blank wells (PBS only) were run on each 96 -well plate during ELISA measurement. The mean of the blank values on a plate was subtracted from other values on a plate to correct for background. Bayesian inference was used to estimate posterior parameter distributions for all analyses. Eight chains each took 10,000 samples using the NUTS sampler implemented in pymc3 [25]. Excellent convergence was achieved in all analyses.

\section{Sigmoid curves}

A four parameter logistic curve was used to model the OD of sample i (y_i) as a response to log dilution (x_i) (Fig. S1) [26]: y_i dnorm $\left(c+d \_i /\left(1+\exp \left(-b\left(x \_i-a \_i\right)\right), s\right) . x \_i\right.$ was calculated as $\log 4(t / 40)$ where $t$ is the dilution. a (the horizontal location of the sigmoid) was modelled with no pooling between samples whereas $b$ (the gradient) and $d$ (the difference between minimum and maximum response) were modelled with partial pooling between samples. Given that OD values were background adjusted, c (the minimum response) was fixed at zero. Graphical interpretations of each parameter is shown in Fig. S1. Weakly informative priors were used: a_i dnorm(u_a, s_a), b dnorm $(0,1), d \_i \sim \operatorname{dexp}\left(s \_d\right)$, u_a $\sim \operatorname{dnorm}(0,1)$, s_a $\sim \operatorname{dexp}(1)$, s_d $\sim \operatorname{dexp}(1)$. Log dilution was standardized to have mean of zero and standard deviation of one for all inference. Inflection titers are computed using the mean value of the posterior distribution of a for each sample as: $40\left(4^{* *}\right.$ a_i $)$.

\section{Seroconversion probabilities}

We used robust logistic regression to estimate the probability of seroconversion based on ELISA OD values measured against SARS-CoV-2 RBD and S1S2 antigens at a dilution of 1:40. Negative (pre-pandemic samples) or positive SARS-CoV-2 infection status (PCR-positive samples) was 
medRxiv preprint doi: https://doi.org/10.1101/2021.09.13.21263523; this version posted September 21, 2021. The copyright holder for this preprint (which was not certified by peer review) is the author/funder, who has granted medRxiv a license to display the preprint in perpetuity.

It is made available under a CC-BY-NC-ND 4.0 International license .

encoded as zero or one, respectively, and modelled as: y_i dbern(alpha / 2 + (1 - alpha) f(b_0 +b_R x_Ri + b_S x_Si)). Where b_R and b_S are the effect size estimates of RBS and S1S2 and $\mathrm{x}$ _Ri and $\mathrm{x}$ _Si is the OD value against RBD or $S 1 S 2$ in individual $i, f$ is the standard logistic function: $f(x)=1 /(1+\exp (-x))$. The regression is 'robust' due to alpha; when alpha $=1$, the probability a sample is positive is 0.5 and independent of the $b$ coefficients or OD values. Outliers, such as those caused by false-positive PCR, are accounted for by this random component without impacting the fit of the logistic curve. Weakly informative priors were used: alpha $\sim \mathrm{dbeta}(1,4)$ based on the assumption that outliers should be rare; and beta $j \sim d n o r m(0,1)$. OD values were standardized to have a mean of zero and standard deviation of 1. Samples were partitioned into training and test sets in a ratio of 1:4. Partitioning was stratified so that the ratio of negative to positive samples in the validation set was as close as possible to that in the training set.

\section{Testing difference of group means}

We used a linear model to test the difference of means between two groups. The response ( $\left.y \_i\right)$ was modelled as: $y \_i ~ d s t u d e n t t\left(b \_0+b \_1 x \_i\right.$, nu, sigma). Weakly informative priors were used: b_0 $\sim \operatorname{dnorm}(0,1)$, b_1 $\sim \operatorname{dnorm}(0,1)$, nu $\sim \operatorname{dexp}(1)$, sigma $\sim \operatorname{dexp}(1) . x \_i$ is a binary array indicating group membership of sample i. Data were standardized to have unit variance and a mean of zero. The Student-T, rather than the Normal, distribution was used to be less sensitive to outliers.

\section{Testing differences among groups of paired samples}

We computed the difference between the early and late infection ELISA OD measurements for each individual, delta_i, by subtracting the early value from the late. We then inferred the parameters of a Student-T distribution to describe these differences: delta_i $\sim$ dstudentt(mu, nu, sigma). These priors were used: $\quad \mathrm{mu} \sim \operatorname{dnorm}(0,1), \mathrm{nu} \sim \operatorname{dexp}(1), \operatorname{sigma} \sim \operatorname{dexp}(1)$. The Student-T, rather than the Normal, distribution was used to be less sensitive to outliers. 
medRxiv preprint doi: https://doi.org/10.1101/2021.09.13.21263523; this version posted September 21, 2021. The copyright holder for this

\section{Results}

We tested human serum samples collected before and during the SARS-CoV-2 pandemic for antibodies to SARS-CoV-2 and HCoVs, and used this well-characterized dataset to test a computational approach for substantially reducing the number of serial dilutions needed to robustly measure inflection points (and other arbitrary endpoints) of titration series.

Reactivity of pre-pandemic and SARS-CoV-2 PCR-positive human sera with SARS-CoV-2 $\underline{\text { antigens }}$

First, we measured the reactivity of human serum samples collected before the pandemic and from individuals who were PCR-positive for SARS-CoV-2 against SARS-CoV-2 S1S2, RBD and $\mathrm{N}$ antigens at a single serum dilution of 1:40 (Fig. 1A). Most of the PCR-positive individuals had relatively high OD values against all three SARS-CoV-2 antigens (Fig. 1A); however, a small minority did not react to SARS-CoV-2 antigens which may have been caused by false-positive PCR results. As expected, most pre-pandemic sera lacked reactivity to SARS-CoV-2 antigens (Fig. 1A). A robust logistic regression was fit to the $80 \%$ of the samples (the training set), and used to infer the seropositivity rate. In the test set, $95 \%$ of samples classified as positive (i.e., the assay sensitivity) and $98 \%$ classified as negative (i.e., the assay specificity) were correctly identified. Summarizing all pre-pandemic samples, 2.02\% were SARS-CoV-2 RBD seropositive, 1.61\% were SARS-CoV-2 S1S2 seropositive, and $12.9 \%$ were SARS-CoV-2 N seropositive, consistent with several published studies $[8,9,15]$.

Reactivity of pre-pandemic and SARS-CoV-2 PCR-positive human sera with HCoV antigens

To measure the reactivity of unpaired pre-pandemic and SARS-CoV-2 PCR-positive samples to HCoVs, we conducted ELISAs at a single dilution of 1:40 against the S1S2 and N antigens of the two beta-HCoVs (OC43 and HKU1) and the two alpha-HCoVs (NL63 and 229E, Fig. 2). Conducting a single dilution, rather than multiple, allows higher throughput but may limit assay 
medRxiv preprint doi: https://doi.org/10.1101/2021.09.13.21263523; this version posted September 21, 2021. The copyright holder for this preprint (which was not certified by peer review) is the author/funder, who has granted medRxiv a license to display the preprint in perpetuity.

It is made available under a CC-BY-NC-ND 4.0 International license .

resolution by potentially yielding OD values that are close to the minimum or maximum OD for the assay. Most sera had high OD values to HCoVs, indicating that most individuals have been infected with all four HCoVs, consistent with earlier studies [27-30]. For these unpaired sets of samples, we found very minor or no differences between pre-pandemic and SARS-CoV-2 PCRpositive sera measured against the S1S2 of all HCoVs (Fig. 2). For the N protein, the beta-HCoVs OC43 and HKU1 showed lower reactivity to SARS-CoV-2 PCR-positive sera than pre-pandemic samples, and the alpha-HCoVs showed either no difference (NL63) or a small increase (229E) (Fig. S2).

We also investigated the impact of SARS-CoV-2 infection on OC43 and HKU1 S1S2 and N antigen reactivity using paired human serum samples from COVID-19 patients collected early and late (mean 2.0 and 29.5 days after symptom onset respectively) during SARS-CoV-2 infection (Fig. 3). OD values against OC43 and HKU1 S1S2 proteins increased between early and late samples, demonstrating that SARS-CoV-2 infection increases reactivity to the full-length spike proteins of beta-HCoVs, consistent with other studies [27-30]. There was no systematic increase in OD values for the HKU1 S1 protein (lacking the S2 domain) in ELISA measurements from early to late samples, indicating that the increase in OD values measured against the full-length spike is caused by the S2 domain (Fig. 3).

\section{Serum reactivity analysis with a limited number of serum dilutions}

As stated previously, multiple ELISA measurements from serial dilutions of serum are more informative than measurements based on a single serum dilution but are labor- and resourceconsuming. Here, we investigated if less than eight dilutions can be used to robustly infer inflection and endpoint titers.

For this task, we used 162 human sera with unknown SARS-CoV-2 exposure status collected by the MCRI during the pandemic. First, ELISAs were conducted at eight four-fold dilutions starting 
medRxiv preprint doi: https://doi.org/10.1101/2021.09.13.21263523; this version posted September 21, 2021. The copyright holder for this preprint (which was not certified by peer review) is the author/funder, who has granted medRxiv a license to display the preprint in perpetuity.

It is made available under a CC-BY-NC-ND 4.0 International license .

at 1:40 against SARS-CoV-2 S1S2, RBD, and N. Then, we inferred parameters of sigmoid curves for each sample using all eight dilutions in a Bayesian hierarchical model, and derived inflection titers. Finally, we tested if similar inflection titers can be obtained using subsets of the eight dilutions. Inflection titers can be calculated with high confidence from just three 'spread-out' dilutions (1:40, 1:640, 1:10240; Fig. 4). Highest posterior density intervals (HPDIs) of inflection titers increased at higher titers when only two dilutions (e.g., 1:40 and 1:640) or three consecutive dilutions (e.g., 1:40, 1:160, 1:640) were used (Fig. 4). However, including one additional dilution $(1 ; 40,1: 160,1: 640,1: 2560)$ or spreading out dilutions $(1: 40,1: 640,1: 10240)$ reduces HPDI width, even at high inflection titers (Fig. 4). Thus, highly robust analyses can be conducted from as few as three serum dilutions. To further evaluate our approach, we compared an arbitrarily chosen endpoint cutoff $(O D=0.1)$ calculated from subsets of three or four dilutions to eight dilutions (Fig. S3). As with inflection titers, endpoint titers inferred from only three serum dilutions correlated very closely with those inferred from eight serum dilutions $\left(R^{2} \geq 0.97\right)$.

To test our approach further, we measured ELISA OD values using a dilution series of 1:40, 1:640, and 1:10240 to infer inflection titers for the S1S2 protein of the beta-HCoVs HKU1 and OC43 against pre-pandemic and SARS-CoV-2 PCR-positive human serum samples. Inflection titers were higher in SARS-CoV-2 PCR-positive samples than pre-pandemic samples (Fig. 5). This is different to the pattern shown in Fig. 2 where there is no difference between pre-pandemic and PCR-positive samples in OC43 S1S2 and only a very small difference in HKU1 S1S2. This illustrates the importance of conducting measurements across serial dilutions, especially if the single dilution used generates $O D$ values close to the minimum or maximum OD value of an assay. In this case, at a dilution of 1:40 the OD readout is close to saturation which obscures the differences between groups (Fig. S4). 
medRxiv preprint doi: https://doi.org/10.1101/2021.09.13.21263523; this version posted September 21, 2021. The copyright holder for this

\section{Discussion}

Here, we used human sera collected during the SARS-CoV-2 pandemic to demonstrate that it is possible to robustly infer inflection and endpoint titers from fewer than the typically used 8-12 serial dilutions. In fact, three widely spaced dilutions $(1: 40,1: 640,1: 10240)$ provide the same information as eight consecutive dilutions. Thus, researchers could conduct a pilot study on a small number of samples with 8-12 dilutions, infer inflection (or endpoint) titers, and identify a subset of dilutions that can be used to obtain equally accurate results. Routine analysis with large sets of sera could then be carried out with only the minimal set of dilutions.

Our approach is based on fitting sigmoid curves, rather than simply identifying the serum dilution at which a predetermined endpoint is reached. This approach has several advantages; we show it substantially reduces the number of dilutions required, reducing resources, effort and/or increasing throughput. It also generates readings on a continuous scale between discrete dilution folds, increasing assay resolution. Furthermore, multiple data points are used to fit sigmoid curves, meaning individual readings with large error have a smaller impact on the final readout. In systems prone to large sources of error, specific processes for accounting for the error can be included [31].

Hierarchical modelling that enables shared inference of parameters between samples imparts additional benefits and is a large factor in being able to reduce the number of dilutions required. For instance, if all samples tend to the same maximal response at high concentration, as is the case in this study, it is unnecessary to ensure that the dilution series allows the same maximal response to be inferred in every sample independently. Rather, dilutions should be positioned in the variable region of the response, and inference of the maximal response should be fully pooled. Additional modelling choices can further reduce dilutions required. In this system it was known a priori that OD values tend to zero as concentration decreases (after subtracting the background 
medRxiv preprint doi: https://doi.org/10.1101/2021.09.13.21263523; this version posted September 21, 2021. The copyright holder for this preprint (which was not certified by peer review) is the author/funder, who has granted medRxiv a license to display the preprint in perpetuity.

It is made available under a CC-BY-NC-ND 4.0 International license .

reading). Therefore, it is unnecessary to conduct measurements at very low concentration because this information can be expressed in the model by setting $c=0$.

Reducing the number of dilutions required to infer parameters of a sigmoid curve is not restricted to analysis of ELISA OD measurements. Assays conducted on a serially diluted sample are common in virology [32,33] and widespread in biology generally [20]. When applying this approach to novel systems, choice of which parameters are fully versus partially pooled, or fixed at a certain value, depends on the nature of the assay, the data, and the question being addressed. Pilot experiments should guide choice of a dilution series that will allow accurate inference (Fig. 4).

We have released $R$ and python packages to fit sigmoid curves using minimal datasets (https://github.com/IRI-UW-Bioinformatics/inflection-titer). Other dose-response curve packages exist [20], however this implementation specifically focuses on hierarchical modelling across samples using Bayesian inference [25,34], both features which are absent from existing packages [20].

Here, we measured cross-reactivity to SARS-CoV-2 S1S2, RBD, and N antigens in human serum samples collected before the emergence of SARS-CoV-2 and found similar rates as those reported elsewhere $[8,9,15]$. We also measured how patterns of reactivity to seasonal HCoVs changed as a result of the SARS-CoV-2 pandemic. We see robust increases in reactivity to seasonal beta-HCoVs in two different comparisons: pre-pandemic versus SARS-CoV-2 PCRpositive sera (Fig. 5), and sera collected early versus late after a confirmed SARS-CoV-2 infection (Fig. 3). The latter demonstrates that the increase in beta-HCoVs antigen titers is the result of SARS-CoV-2 infection, rather than individuals with existing high titers to beta-HCoVs being more likely to be infected with SARS-CoV-2. This effect is masked in our analysis of 1:40 diluted sera (Fig. 2) because most measurements are near the saturation OD reading (Fig. S4). Our findings 
medRxiv preprint doi: https://doi.org/10.1101/2021.09.13.21263523; this version posted September 21, 2021. The copyright holder for this preprint (which was not certified by peer review) is the author/funder, who has granted medRxiv a license to display the preprint in perpetuity. It is made available under a CC-BY-NC-ND 4.0 International license .

are consistent with other reports, although some differences exist among the studies: while several studies reported increases in HKU1 and OC43 spike protein titers in pandemic compared to pre-pandemics samples [9-11], others found increased OC43 (but not HKU1) reactivity [16]. Such differences may be a consequence of the diverse nature of cohorts used and variable circulation of individual HCoVs during the years that samples were collected.

\section{Acknowledgements}

The authors would like to thank Huong McLean, Jennifer King, Ed Belongia of the MCRI, Marshfield, Wisconsin, USA, for human serum sample collection. 


\section{Figures and Tables}
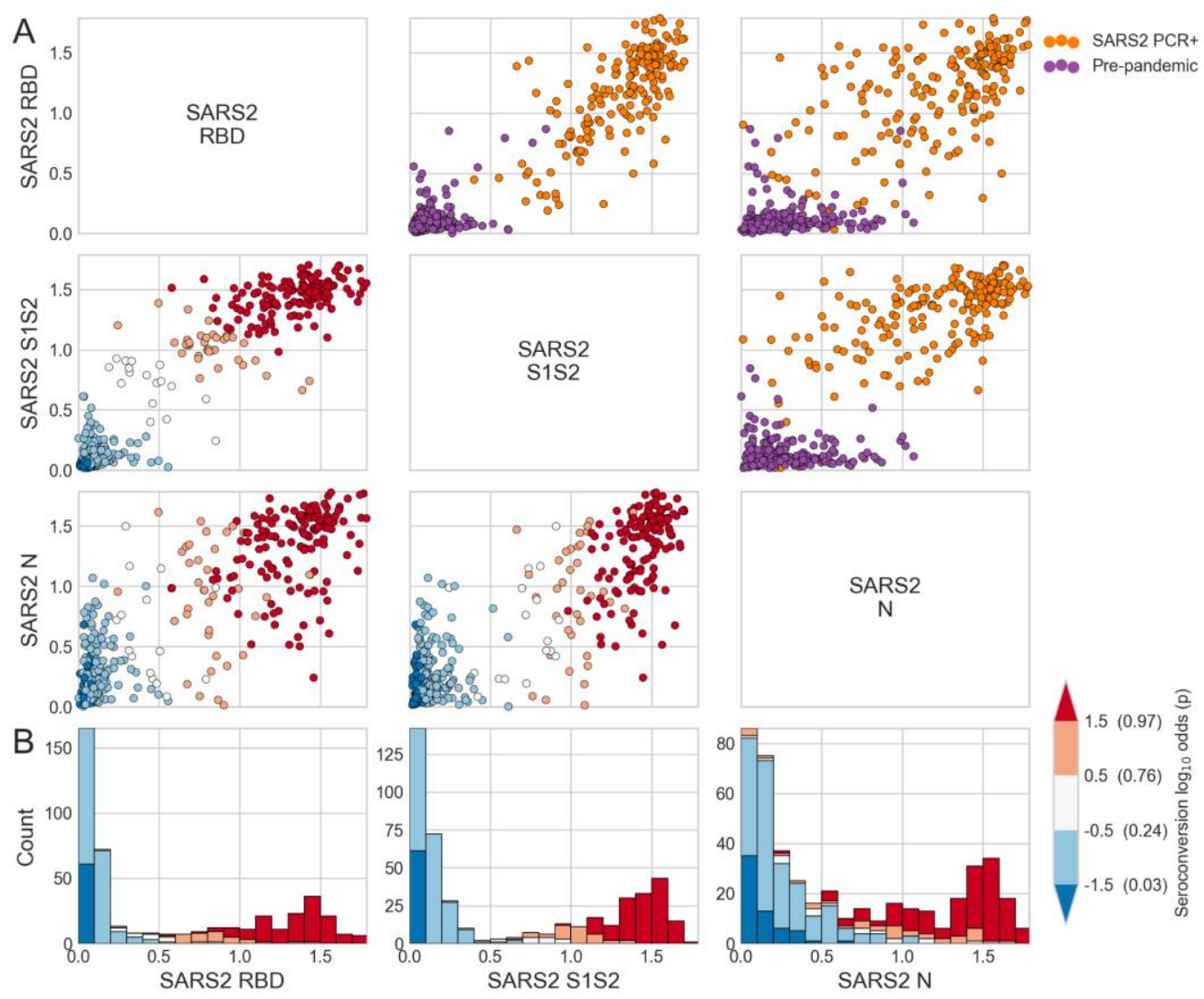

Fig. 1. Reactivity to SARS-CoV-2 (SARS2) spike and N antigens in pre-pandemic and SARS-

CoV-2 PCR-positive human serum samples. (A) Scatter matrix of ELISA OD values of human serum samples collected before the outbreak of SARS-CoV-2 and from individuals that tested PCR-positive for SARS-CoV-2 measured against three SARS-CoV-2 antigens. Individual columns and rows show OD values of one SARS-CoV-2 antigen (RBD, S or N). Subplots above the main diagonal are colored by binary infection status. Subplots below the main diagonal are colored by seroconversion log odds. B) Histograms display the distribution of measurements for individual antigens and are colored by seroconversion log odds. 
medRxiv preprint doi: https://doi.org/10.1101/2021.09.13.21263523; this version posted September 21, 2021. The copyright holder for this preprint (which was not certified by peer review) is the author/funder, who has granted medRxiv a license to display the preprint in perpetuity.

It is made available under a CC-BY-NC-ND 4.0 International license .
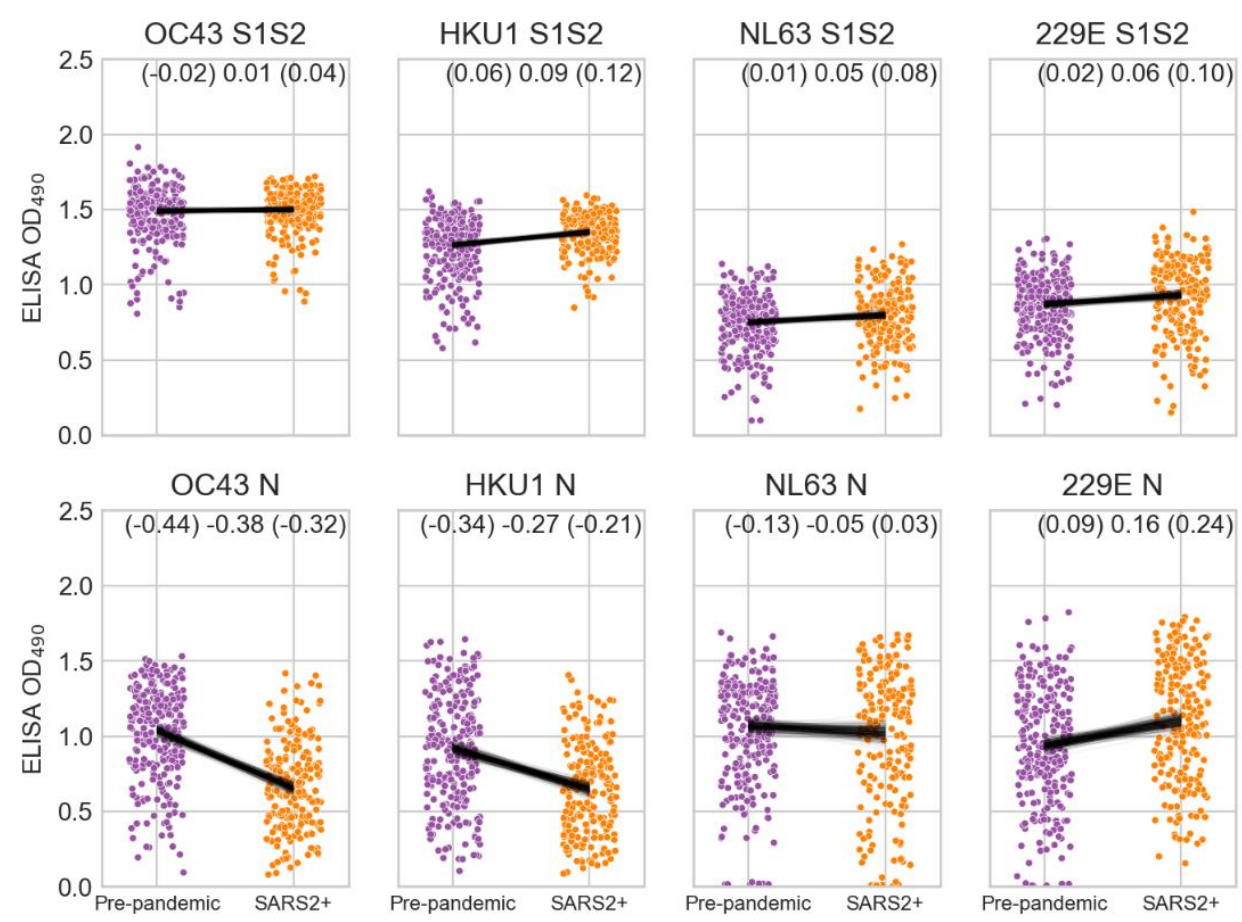

Fig. 2. Reactivity of pre-pandemic and SARS-CoV-2 PCR-positive human sera (SARS2+) to

HCoV antigens. ELISA OD values for 1:40 diluted serum against HCoV S1S2 and N proteins.

Black lines are the posterior distribution of differences in group means inferred from a linear model using Student-T distributed error. The upper and lower boundaries and mean of the 95\% highest posterior density interval of difference in group means is shown in the top right. 
medRxiv preprint doi: https://doi.org/10.1101/2021.09.13.21263523; this version posted September 21, 2021. The copyright holder for this preprint (which was not certified by peer review) is the author/funder, who has granted medRxiv a license to display the preprint in perpetuity.

It is made available under a CC-BY-NC-ND 4.0 International license .
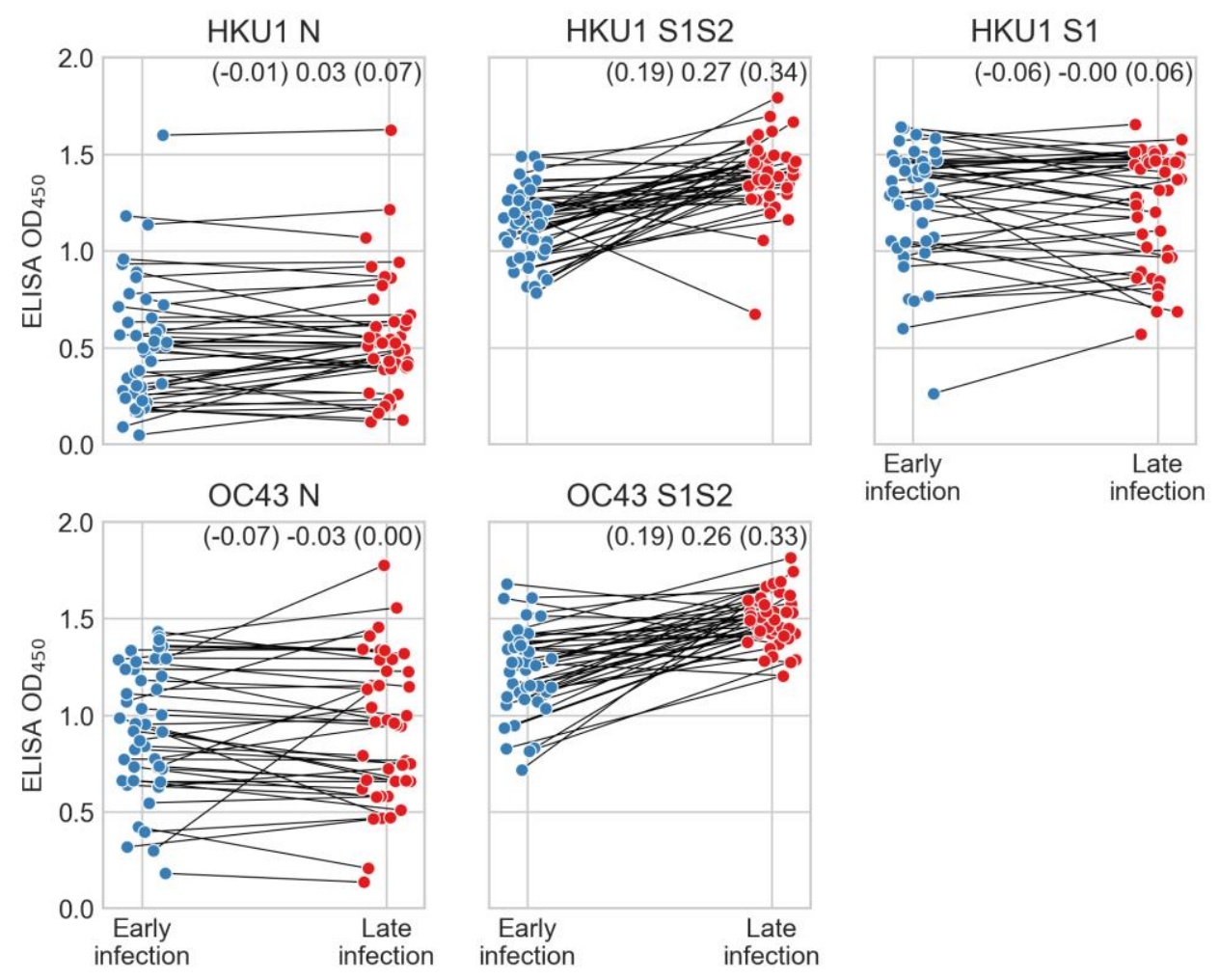

Fig. 3. Reactivity to beta HCoV antigens during SARS-CoV-2 infection. ELISA reactivity of human antisera collected early and late during SARS-CoV-2 infection against beta-HCoV proteins. Lines connect early and late samples from the same individuals. Student-T distributions were fit to paired differences between late and early infection measurements. Upper and lower boundaries and mean of the $95 \%$ highest posterior density interval of the Student-T distribution mean are indicated. 
medRxiv preprint doi: https://doi.org/10.1101/2021.09.13.21263523; this version posted September 21, 2021. The copyright holder for this preprint (which was not certified by peer review) is the author/funder, who has granted medRxiv a license to display the preprint in perpetuity.

It is made available under a CC-BY-NC-ND 4.0 International license .
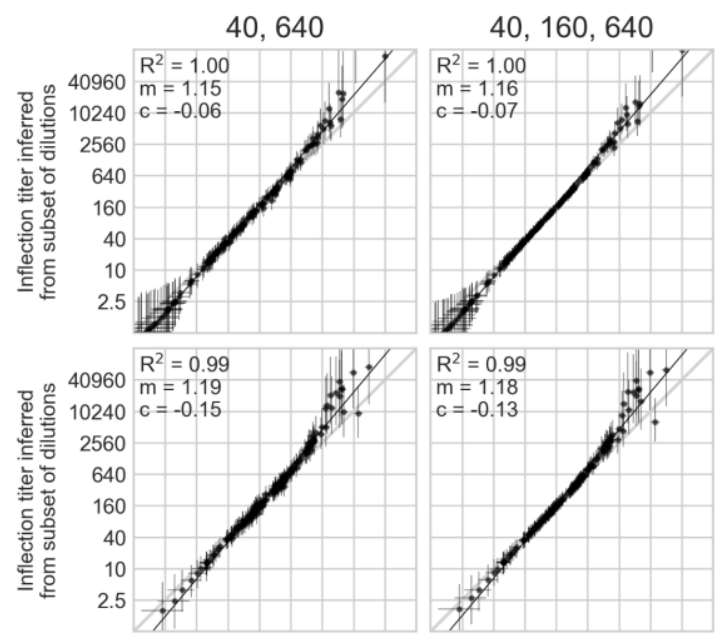

$40,160,640,2560$
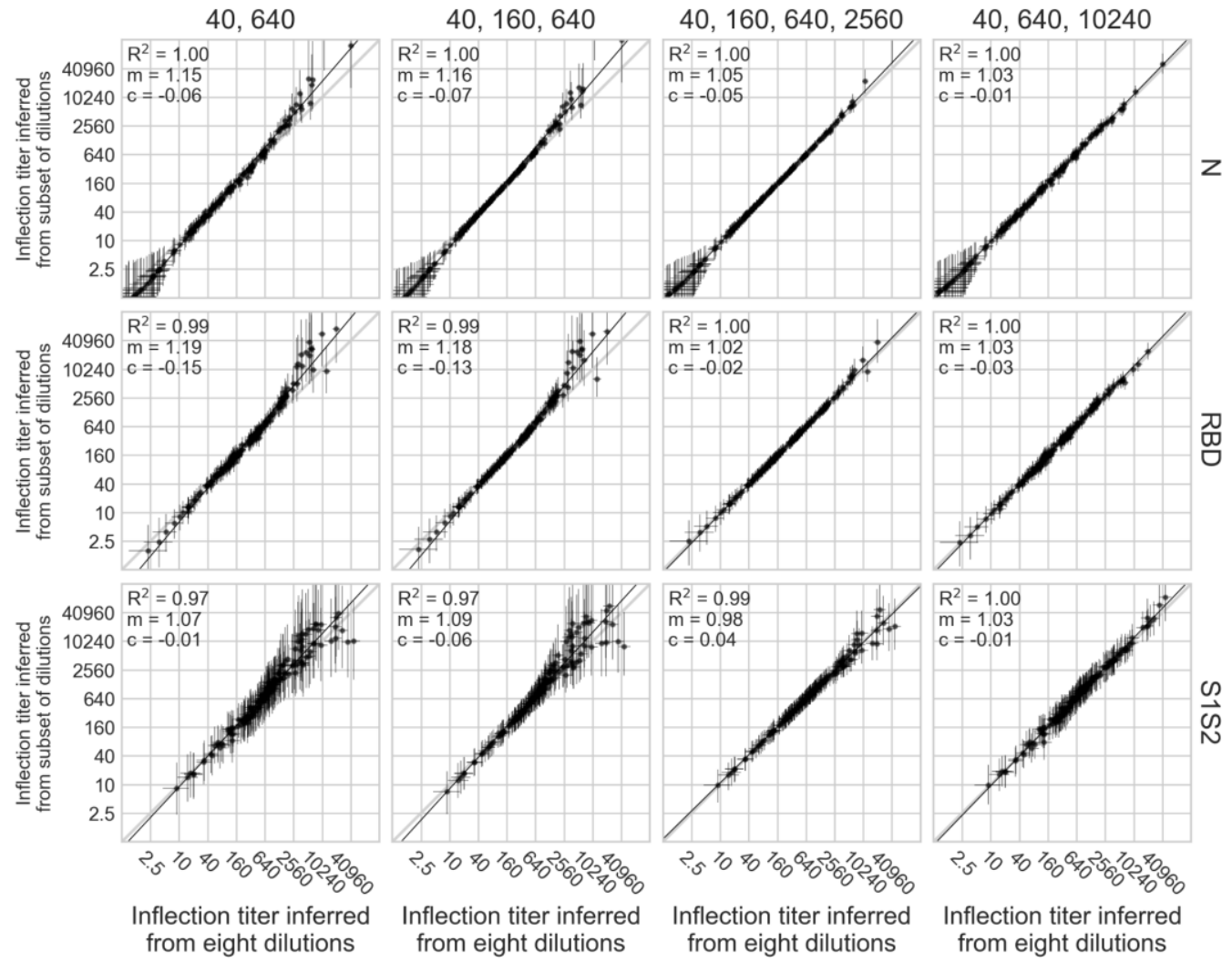

Fig. 4. Inferring inflection titers from minimal dilution series. Inflection titers were computed using eight four-fold dilution series starting at 1:40; this value is shown on the $x$-axes. Inflection titers were also computed using different subsets of dilutions: (40, 640), (40, 160, 640), (40, 160, $640,2560)$ and $(40,640,10240)$; these values are shown on the y-axes. Ordinary least squares linear regression was conducted on each $x$ and $y$ series. $R$ squared, slope $(m)$ and intercept $(c)$ are indicated on each plot. Error bars indicate the $95 \%$ highest posterior density interval of the posterior distribution of the inflection titer. 

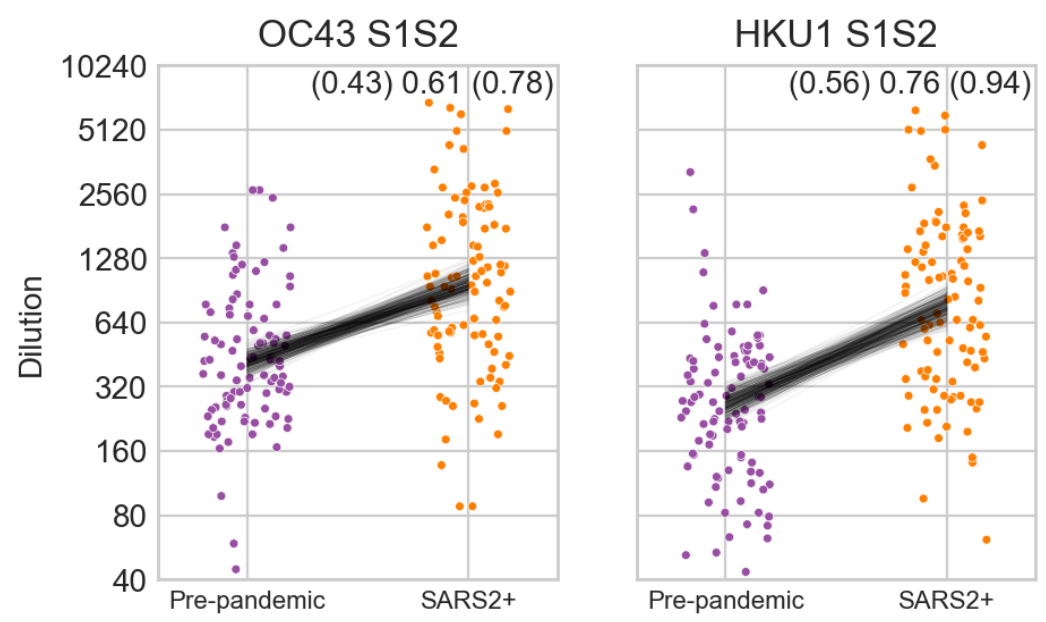

Fig. 5. Inflection titers of pre-pandemic and SARS-CoV-2 PCR positive human sera (SARS2+) to beta-HCoV S1S2 proteins. Black lines show the posterior distribution of differences in group means inferred from a linear model using Student-T distributed error. The upper and lower boundaries and mean of the $95 \%$ highest posterior density interval of difference in group means is shown in the top right; one unit is a single four-fold dilution. 


\section{References}

1. Zhu N, Zhang D, Wang W, et al. A Novel Coronavirus from Patients with Pneumonia in China, 2019. N Engl J Med. 2020; 382(8):727-733.

2. WHO Director-General's opening remarks at the media briefing on COVID-19 - 11 March 2020 [Internet]. World Health Organization. 2020 [cited 2021 Apr 6]. Available from: https://www.who.int/director-general/speeches/detail/who-director-general-s-openingremarks-at-the-media-briefing-on-covid-19---11-march-2020

3. WHO Coronavirus (COVID-19) Dashboard [Internet]. World Health Organisation. 2021 [cited 2021 Aug 16]. Available from: https://covid19.who.int

4. Lakner C, Yonzan N, Mahler DG, Aguilar RAC, Wu H. Updated estimates of the impact of COVID-19 on global poverty: Looking back at 2020 and the outlook for 2021 [Internet]. World Bank. 2021 [cited 2021 Apr 26]. Available from: https://blogs.worldbank.org/opendata/updatedestimates-impact-covid-19-global-poverty-looking-back-2020-and-outlook-2021

5. Gaunt ER, Hardie A, Claas ECJ, Simmonds P, Templeton KE. Epidemiology and clinical presentations of the four human coronaviruses 229E, HKU1, NL63, and OC43 detected over 3 years using a novel multiplex real-time PCR method. J Clin Microbiol. Am Soc Microbiol; 2010; 48(8):2940-2947.

6. Su S, Wong G, Shi W, et al. Epidemiology, Genetic Recombination, and Pathogenesis of Coronaviruses. Trends Microbiol. 2016; 24(6):490-502.

7. Corman VM, Muth D, Niemeyer D, Drosten C. Hosts and Sources of Endemic Human Coronaviruses. Adv Virus Res. 2018; 100:163-188.

8. Yue F, Lidenge SJ, Peña PB, Clegg AA, Wood C. High prevalence of pre-existing serological 
medRxiv preprint doi: https://doi.org/10.1101/2021.09.13.21263523; this version posted September 21, 2021. The copyright holder for this preprint (which was not certified by peer review) is the author/funder, who has granted medRxiv a license to display the preprint in perpetuity.

It is made available under a CC-BY-NC-ND 4.0 International license .

cross-reactivity against severe acute respiratory syndrome coronavirus-2 (SARS-CoV-2) in sub-Saharan Africa. Int J Infect Dis. 2020; 102:557-583.

9. Hicks J, Klumpp-Thomas C, Kalish H, et al. Serologic cross-reactivity of SARS-CoV-2 with endemic and seasonal Betacoronaviruses. medRxiv [Internet]. 2020; . Available from: http://dx.doi.org/10.1101/2020.06.22.20137695

10. Anderson EM, Goodwin EC, Verma A, et al. Seasonal human coronavirus antibodies are boosted upon SARS-CoV-2 infection but not associated with protection. Cell. $2021 ;: 1-7$.

11. Westerhuis BM, Aguilar-Bretones M, Raadsen MP, et al. Severe COVID-19 patients display a back boost of seasonal coronavirus-specific antibodies. medRxiv [Internet]. 2020; 4550. Available from: http://dx.doi.org/10.1101/2020.10.10.20210070

12. Guo L, Wang Y, Kang L, et al. Cross-reactive antibody against human coronavirus OC43 spike protein correlates with disease severity in COVID-19 patients: a retrospective study. https://doi.org/101080/2222175120211905488. Taylor \& Francis; 2021; 10(1):664-676.

13. Henss L, Scholz T, Von Rhein C, et al. Analysis of Humoral Immune Responses in Patients with Severe Acute Respiratory Syndrome Coronavirus 2 Infection. J Infect Dis. Oxford University Press; 2021; 223(1):56-61.

14. Morgenlander WR, Henson SN, Monaco DR, et al. Antibody responses to endemic coronaviruses modulate COVID-19 convalescent plasma functionality. J Clin Invest [Internet]. American Society for Clinical Investigation; 2021; 131(7). Available from: https://doi.org/10.1172/JCl146927.

15. Simula ER, Manca MA, Jasemi S, et al. HCoV-NL63 and SARS-CoV-2 share recognized epitopes by the humoral response in sera of people collected pre-and during CoV-2 pandemic. Microorganisms. 2020; 8(12):1-15. 
medRxiv preprint doi: https://doi.org/10.1101/2021.09.13.21263523; this version posted September 21, 2021. The copyright holder for this preprint (which was not certified by peer review) is the author/funder, who has granted medRxiv a license to display the preprint in perpetuity.

It is made available under a CC-BY-NC-ND 4.0 International license .

16. Song G, He W-T, Callaghan S, et al. Cross-reactive serum and memory B-cell responses to spike protein in SARS-CoV-2 and endemic coronavirus infection. Nat Commun [Internet]. 2021; 12(1). Available from: http://dx.doi.org/10.1101/2020.09.22.308965

17. Sharwani K, Sharma R, Krishnan M, et al. Detection of serum cross-reactive antibodies and memory response to SARS-CoV-2 in pre-pandemic and post-COVID-19 convalescent samples. J Infect Dis [Internet]. 2021; . Available from: http://dx.doi.org/10.1093/infdis/jiab333

18. Song G, He W-T, Callaghan S, et al. Cross-reactive serum and memory B-cell responses to spike protein in SARS-CoV-2 and endemic coronavirus infection [Internet]. Nature Communications. 2021. Available from: http://dx.doi.org/10.1038/s41467-021-23074-3

19. Rucinski SL, Binnicker MJ, Thomas AS, Patel R. Seasonality of Coronavirus 229E, HKU1, NL63, and OC43 From 2014 to 2020. Mayo Clin Proc. 2020; 95(8):1701-1703.

20. Ritz C, Baty F, Streibig JC, Gerhard D. Dose-response analysis using R. PLoS One. 2015; 10(12):1-13.

21. Frey A, Di Canzio J, Zurakowski D. A statistically defined endpoint titer determination method for immunoassays. J Immunol Methods. 1998; 221:35-41.

22. Amanat F, Stadlbauer D, Strohmeier S, et al. A serological assay to detect SARS-CoV-2 seroconversion in humans. medRxiv [Internet]. 2020; . Available from: http://dx.doi.org/10.1101/2020.03.17.20037713

23. Hsieh CL, Goldsmith JA, Schaub JM, et al. Structure-based design of prefusion-stabilized SARS-CoV-2 spikes. Science

24. Yamayoshi S, Yasuhara A, Ito M, et al. Antibody titers against SARS-CoV-2 decline, but do not disappear for several months. EClinicalMedicine [Internet]. Elsevier; 2021; 32. Available 
medRxiv preprint doi: https://doi.org/10.1101/2021.09.13.21263523; this version posted September 21, 2021. The copyright holder for this preprint (which was not certified by peer review) is the author/funder, who has granted medRxiv a license to display the preprint in perpetuity.

It is made available under a CC-BY-NC-ND 4.0 International license .

from: https://doi.org/10.1016/j.eclinm.2021.100734

25. Salvatier J, Wiecki TV, Fonnesbeck C. Probabilistic programming in Python using PyMC3. PeerJ Computer Science. PeerJ Inc.; 2016; 2:e55.

26. Karpinski KF, Hayward S, Tryphonas H. Statistical considerations in the quantitation of serum immunoglobulin levels using the enzyme-linked immunosorbent assay (ELISA). J Immunol Methods. 1987; 103(2):189-194.

27. Shao X, Guo X, Esper F, Weibel C, Kahn JS. Seroepidemiology of group I human coronaviruses in children. J Clin Virol. 2007; 40(3):207-213.

28. Dijkman R, Jebbink MF, Idrissi NBE, Pyrc K, Muller MA, Kuipers TW, Zaaijer HL, van der Hoek L. Human coronavirus NL63 and 229E seroconversion in children. J Clin Microbiol. 2008; 46(7):2368-73.

29. Dijkman R, van der Hoek L. Human coronaviruses 229E and NL63: close yet still so far. J Formos Med Assoc. 2009; 108(4):270-9.

30. Zimmermann P, Curtis N. Coronavirus Infections in Children Including COVID-19: An Overview of the Epidemiology, Clinical Features, Diagnosis, Treatment and Prevention Options in Children. Pediatr Infect Dis J. 2020; 39(5):355-368.

31. Hogg DW, Bovy J, Lang D. Data analysis recipes: Fitting a model to data. 2010; . Available from: http://arxiv.org/abs/1008.4686

32. Westgeest KB, Bestebroer TM, Spronken MIJ, et al. Optimization of an enzyme-linked lectin assay suitable for rapid antigenic characterization of the neuraminidase of human influenza A(H3N2) viruses. J Virol Methods. 2015; 217:55-63.

33. Gao J, Couzens L, Eichelberger MC. Measuring Influenza Neuraminidase Inhibition Antibody 
medRxiv preprint doi: https://doi.org/10.1101/2021.09.13.21263523; this version posted September 21, 2021. The copyright holder for this preprint (which was not certified by peer review) is the author/funder, who has granted medRxiv a license to display the preprint in perpetuity. It is made available under a CC-BY-NC-ND 4.0 International license .

Titers by Enzyme-linked Lectin Assay. J Vis Exp [Internet]. 2016; (115). Available from: http://dx.doi.org/10.3791/54573

34. Team SD, Others. RStan: The $R$ interface to Stan. $R$ package version 2.17. 3. Online: http://mc-stan org. 2018. 


\section{Supplementary Material}

A
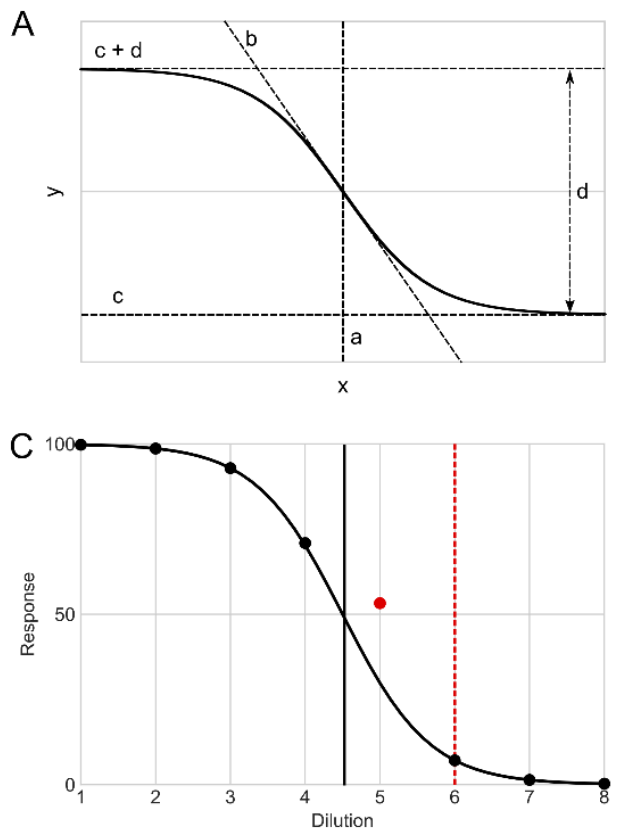
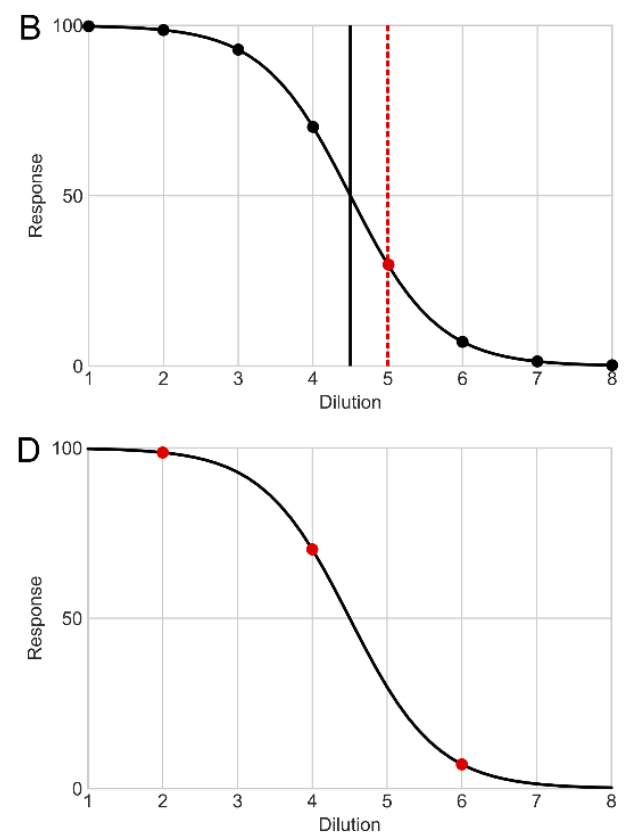

Fig. S1 (A) Four parameter sigmoid function. $y=c+d /(1+\exp -b(x-a))$. a defines the horizontal location of the curve on the $x$ axis. $b$ sets the gradient of the curve. $c$ sets the minimum $y$ value, and $d$ sets the distance between the minimum and maximum y value. The $x$-axis shows the index of the dilution series. (B) Discretizing reduces precision. The first dilution underneath a $50 \%$ response (red point) is 5 , but the true inflection point is 4.5 (black vertical line). (C) Overreliance on individual measurements. The measurement at dilution 5 is erroneous, so the first dilution underneath a $50 \%$ response is 6 (red dotted line), but the true EC50 is 4.5 (black line). (D) Sigmoid curves can be fit with fewer dilutions than are commonly conducted. Statistics of interest (e.g. inflection points or endpoints) can then be computed from the curve. Hierarchical modelling of multiple samples that share curve characteristics improves the inference of individual samples. 
medRxiv preprint doi: https://doi.org/10.1101/2021.09.13.21263523; this version posted September 21, 2021. The copyright holder for this preprint (which was not certified by peer review) is the author/funder, who has granted medRxiv a license to display the preprint in perpetuity.

It is made available under a CC-BY-NC-ND 4.0 International license .

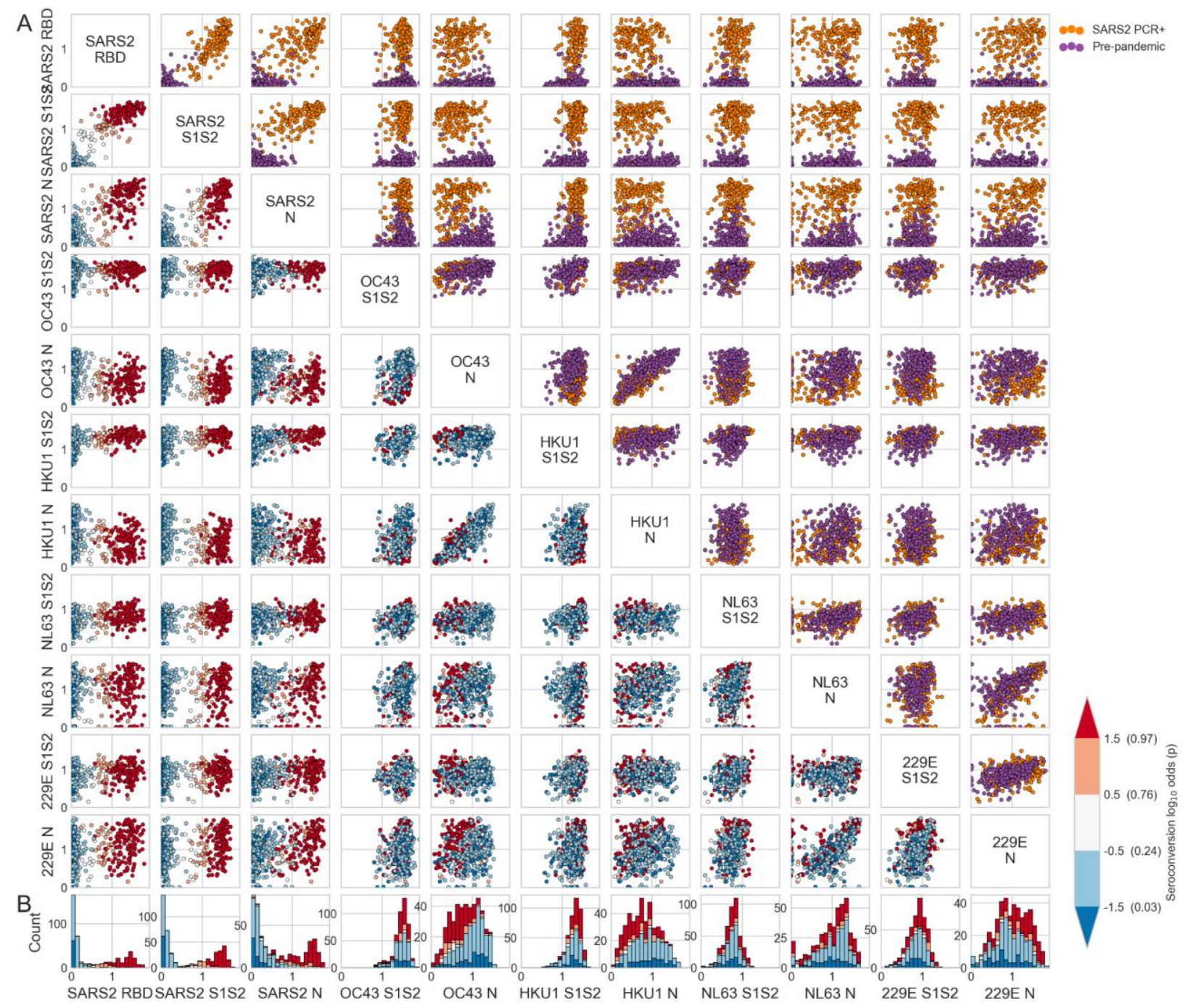

Fig. S2. Reactivity to SARS-CoV-2, OC43, HKU1, NL63, 229E spike and N antigens in prepandemic and SARS-CoV-2 PCR-positive human serum samples. (A) Scatter-matrix of ELISA OD measurements for 1:40 diluted serum samples. Above the main diagonal colors indicate whether a sample was collected before the pandemic or from a SARS-CoV-2 PCRpositive individual. Below the main diagonal, colors indicate SARS-CoV-2 seroconversion log odds. (B) Histograms display univariate distributions in each column and are colored by seroconversion log odds. 
medRxiv preprint doi: https://doi.org/10.1101/2021.09.13.21263523; this version posted September 21, 2021. The copyright holder for this preprint (which was not certified by peer review) is the author/funder, who has granted medRxiv a license to display the preprint in perpetuity.

It is made available under a CC-BY-NC-ND 4.0 International license .
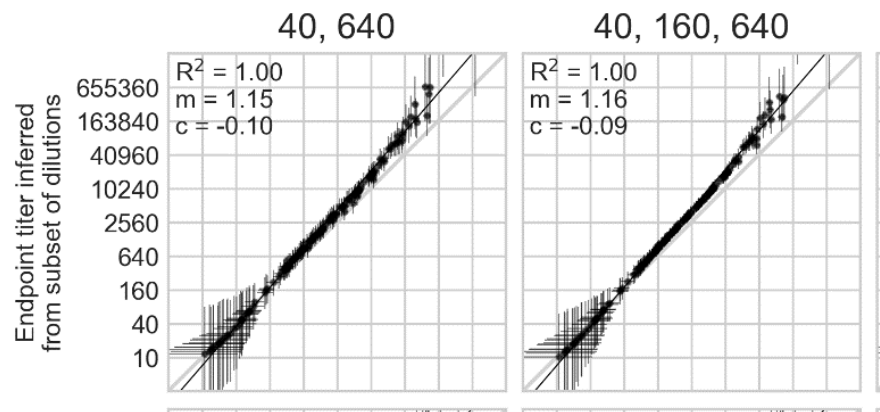

$40,160,640,2560$
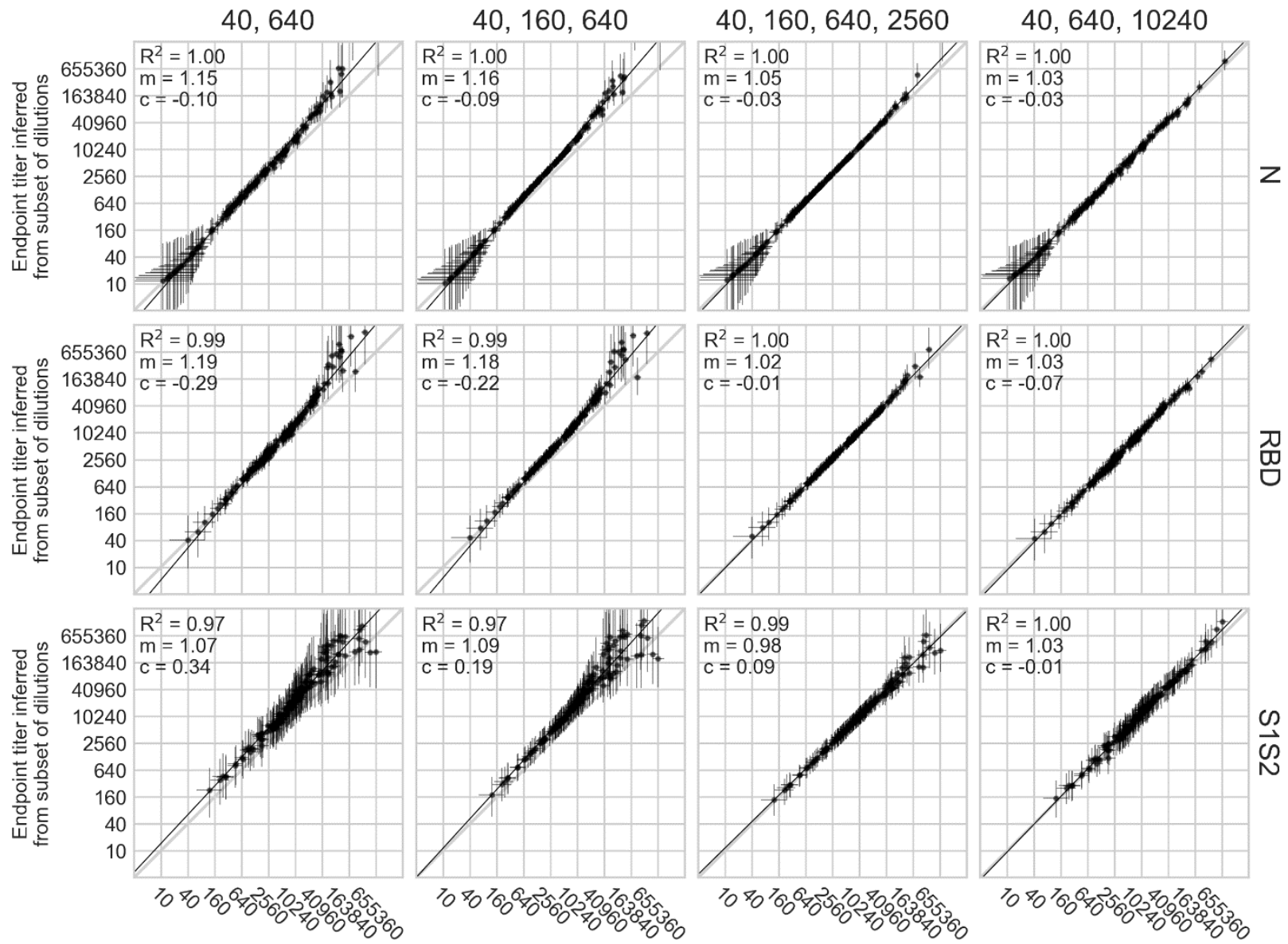

Endpoint titer inferred Endpoint titer inferred from eight dilutions from eight dilutions

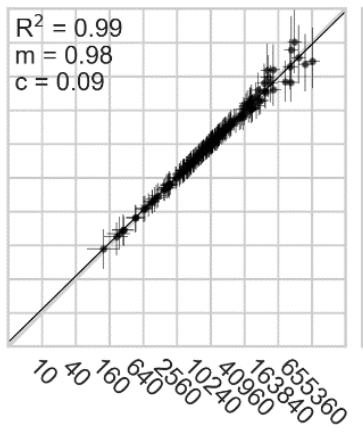

Endpoint titer inferred from eight dilutions

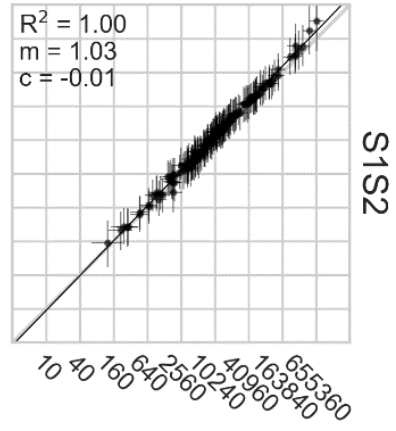

Endpoint titer inferred from eight dilutions

Fig. S3. Inferring endpoint titers from minimal dilution series. As Fig. 3, except here we performed the analysis for an arbitrarily chosen endpoint titer, defined here as the serum concentration that would yield an OD reading of 0.1 . 

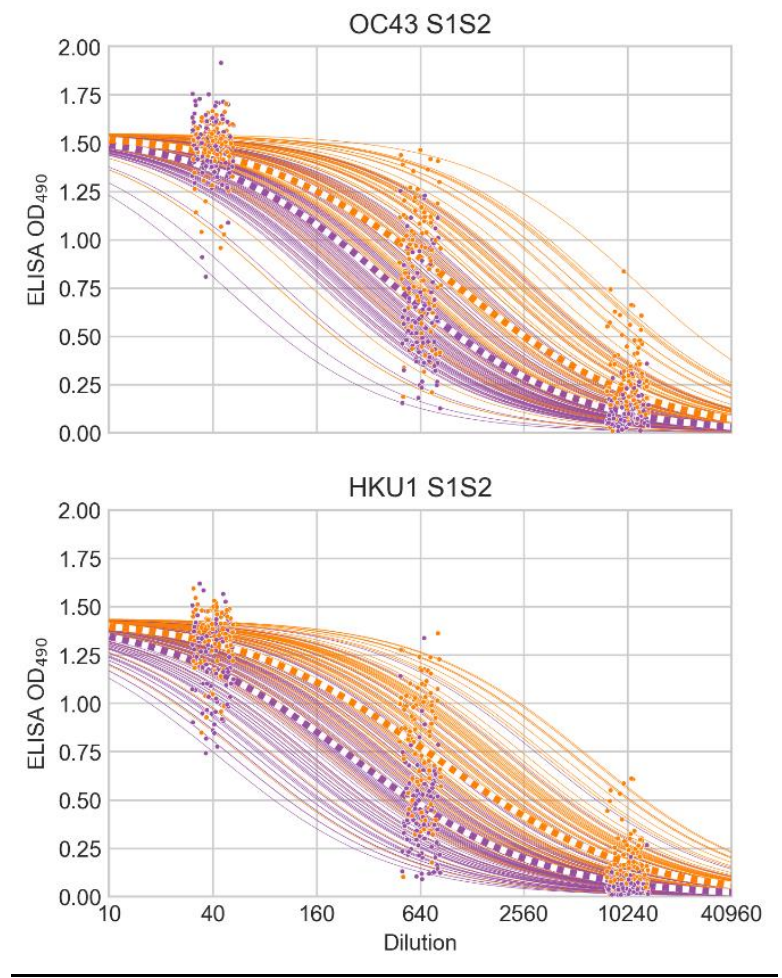

Fig. S4. Dilution series of OC43 and HKU1 S1S2. Thin solid lines show sigmoid curves for prepandemic (purple) and PCR-positive (orange) samples fit to OD values from their dilution series (points). Thick dashed lines indicate the mean curve of each group. A small amount of $x$-axis jitter has been added to the points to prevent overplotting. Curves are drawn using the mean of the parameter posterior distributions. The difference between groups for OC43 S1S2 when only looking at OD values from the 1:40 dilution (Fig. 2) is substantially smaller than the difference between the inflection titers (Fig. 5). This is caused by the OD measurement becoming saturated at 1:40. Similarly, for HKU1 the difference between groups is smaller at the single dilution of 1:40 (Fig. 2) than it is when comparing inflection titers (Fig. 5). 
Table S1. Summary of human serum panels.

\begin{tabular}{|c|c|c|}
\hline Panel & Description & $\mathrm{n}$ \\
\hline Pre-pandemic & $\begin{array}{l}\text { Obtained before emergence of SARS-CoV-2, } \\
\text { between } 2013 \text { and April } 2019 \text { by the Institute for } \\
\text { Influenza Research, UW Madison. }\end{array}$ & 248 \\
\hline UWH PCR positive & $\begin{array}{l}\text { PCR-positive for SARS-CoV-2 from University of } \\
\text { Wisconsin Hospital. }\end{array}$ & 188 \\
\hline Commercial positive & $\begin{array}{l}\text { SARS-CoV-2 positive antisera purchased from } \\
\text { Lampire Biological Laboratories. }\end{array}$ & 12 \\
\hline EGH early infection & $\begin{array}{l}\text { Paired samples collected from SARS-CoV-2 } \\
\text { patients soon after diagnosis at the Eiju General } \\
\text { Hospital. }\end{array}$ & 44 \\
\hline EGH late infection & $\begin{array}{l}\text { Paired samples collected from SARS-CoV-2 } \\
\text { patients late during infection at the Eiju General } \\
\text { Hospital. }\end{array}$ & 44 \\
\hline MCRI & $\begin{array}{l}\text { Samples collected after the emergence of SARS- } \\
\text { CoV-2 from participants of a community cohort } \\
\text { study by the Marshfield Clinic Research Institute. }\end{array}$ & 162 \\
\hline
\end{tabular}

